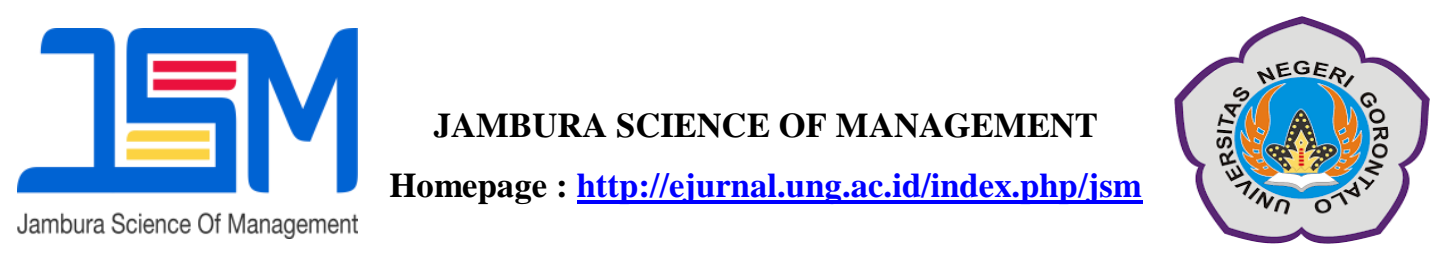

\title{
The Influence of Intellectual Capital on the Profitability of Banking Companies
}

\author{
Agustin Sri Mutiara Gani ${ }^{1}$, Rizan Machmud ${ }^{2}$, Selvi ${ }^{3}$ \\ ${ }^{123}$ Department of Management, Economic Faculty, Gorontalo State University \\ E-mail: agustinsmgani@gmail.com
}

\begin{abstract}
:
This research is motivated by a decrease in profitability in several companies over the last few years. The purpose of this study is to determine the effect of intellectual capital on the decline in profitability of banking companies over the past few years. This study has two types of variables consisting of dependent variables namely intellectual capital whose indicators are (VACA, VAHU, and STVA), while the independent variable is profitability whose indicators are represented by (ROE) in the 2013-2017 period. The results of this study indicate simultaneously VACA, VAHU, and STVA have an influence on company ROE. Partially VACA, and STVA have a significant influence on company ROE. Whereas VAHU has a negative influence on company ROE. $29.3 \%$ of all variables in this research model namely VACA, VAHU, and STVA have a contribution to affect profitability (ROE)
\end{abstract}

\section{Keywords: Intellectual Capital; Profitabilitas; VACA; VAHU; STVA; ROE}

Each bank produces different profits, the size of the profit generated by a bank can be influenced by several factors. Internal factors can be in the form of management of Human Resources (HR) owned by the bank. The external factors are factors beyond the ability of banks that can affect banks in (profitability), operational efficiency (operational efficiency), and debt (leverage). Also in the calculation indicator Intellectual Capital involves equity and net income (Hendrayanti and Muharram, 2013). In the banking sector, intellectual capital is one of the most significant assets. This is consistent with Firer and Williams's (2003) research which states that the banking industry is one of the sectors that has the most intensive intellectual capital. In order to improve its performance, the banking industry carries out various kinds of information technology-based services to its customers. Moreover, in recent years many banks have begun implementing knowledge-based business. According to Fifer and Williams (2003), knowledgebased management has become a new breakthrough for modern organizations that hope to compete in an environment with increasing pressure.

Intellectual capital means including all processes and assets that are not 
normally shown in the statement of financial position and all intangible assets (trademarks, patents and brands) that modern accounting methods consider including all members' knowledge and practicing their knowledge. Intellectual Capital is basically difficult to understand, but once discovered and exploited it is likely to provide an organization with new resources to compete and win (Roos et al., 1997., Bontis, 1996). The combination of the three value added in Intellectual Capital is symbolized by the name VAIC which consists of several indicators namely VACA, VAHU, and STVA developed by Pulic (1998: 1999: 2000).

While profitability is measured using the ratio of return on equity (ROE), ROE shows the company's ability to generate profits after tax using the company's own capital. According to Kasmir (2018) ROE ratio can show the amount of net profit generated and company productivity using loan capital or own capital.

\section{METHOD}

This research was used quantitative approach. The population used in this study is a banking company listed on the Indonesia Stock Exchange (IDX) which is a State-Owned Commercial Bank (BUMN). The data used in this study are secondary data in the form of annual financial statements of state-owned banks listed on the Indonesia Stock Exchange from 2013 to 2017. The method to be carried out in this study uses the archive method. The data analysis method used is regresion analyzed.

\section{RESULT}

Based on SPSS output data it is known that the calculated $\mathrm{F}$ value is 3.628. The F-table at the 5\% significance level is known through Nk-1, where " $n$ " is the sum of all samples, that is 20 , while " $k$ " is the number of independent variables (numerator free degrees, df1) is 3 , and minus 1 , so the calculation is $20-3-1=16$ then it is known that the $\mathrm{F}$ value of the table is 3.24. F-calculated value obtained is greater than the F-table value, it can be concluded that $\mathrm{H} 0$ is rejected and $\mathrm{H} 1$ is accepted. If using the significance value, the results of the analysis obtained a significance value of 0.036 . This value is very small when compared with the alpha value used, namely at a confidence level of $5 \%$ (0.05). Thus it can be concluded that all independent variables (VACA, VAHU, and STVA) in the research model jointly (simultaneously) have an influence on the profitability (ROE) of SOE Banks listed on the Indonesia Stock Exchange during 2013 to 2017.

By using a significance level of 5\% and a df value of $n-k-1$ ( $n$ is the number of cases and $\mathrm{k}$ is the number of independent variables), so that $20-3-1=16$ a t-table value of 1.746 is obtained. Obtained tvalue for the VACA variable of 2.552 . Furthermore, it is known that the value of $t$ table is 1.746 or $t$ arithmetic is much greater than $t$ table. Based on the significance value, the VACA variable has 
a significance value of 0.021 or much smaller than the alpha probability value with a confidence level of 5\%. (0.05) From this explanation it can be explained that $\mathrm{HO}$ is rejected and $\mathrm{Ha}$ is accepted, or in other words that the VACA variable has a significant effect on the ROE of stateowned banking companies listed on the Stock Exchange in the period 2013 to 2017. Obtained for the VAHU variable of 2,685 Next we know the value of $t$ table is -1.746. Due to the negative value of the VAHU variable, it can be concluded that $\mathrm{Ha}$ is accepted and $\mathrm{HO}$ is rejected, or in other words that the VAHU variable has a negative influence on the ROE of SOE Banks listed on the Indonesia Stock Exchange in 2013 to 2017. Obtained for a variable value STVA of 1.784 Furthermore, it is known that the value of $t$ table is 1.746 or the calculated $t$ value is greater than the value of $t$ table. From this explanation it can be explained that $\mathrm{H} 0$ is rejected and $\mathrm{Ha}$ is accepted, or in other words that STVA has a significant influence on the ROE of SOE Banks listed on the Indonesia Stock Exchange from 2013 to 2017. Or in other words the hypothesis prepared is accepted.

Based on the SPSS output display it is known that the $R$ value is 0.636 , the $R$ square value (R2) is 0.405 , while the Adjusted $\mathrm{R}$ square value is 0.293 . contribution to influence the profitability (ROE) of state-owned banks listed on the Indonesia Stock Exchange in 2013 to 2017, and the remaining $70.7 \%$ of the ROE variable allows to be influenced by other factors (variables) not explained in this study. The small value of the determinant as an explanatory variable $\mathrm{Y}$, can be caused by one variable that has a negative influence on the $\mathrm{Y}$ variable, which in this case is the VAHU variable. the standard error of estimate value of 4.09 (unit price for variable $\mathrm{Y}$ ) is much smaller than the standard deviation value of variable $Y$ (4.87). As a guideline if the Standard error of the estimate is less than the standard deviation of $\mathrm{Y}$, then the regression model is better at predicting the value of $\mathrm{Y}$. This explains that the model produced in this study is very accurate and reliable.

\section{DISCUSSION}

VACA, VAHU, and STVA have an influence on the dependent variable namely ROE of BUMN banks, as evidenced by the calculated $F$ value greater than the $\mathrm{F}$ table value. The influence of all independent variables proves that Value Added Capiptal with VACA, VAHU, and STVA components has the main goal of creating added value in knowing the size of physcal capital (financial funds) and intellectual potential (values inherent in employees' ability resulting from). The VACA variable has a significant effect on ROE of BUMN banks because it is defined as the added value of the company generated from the capital used, or according to (Kartika and Hatane, 2013; in Cahyani et al, 2015), is the company's ability to manage resources in the form of capital assets that if managed properly will improve the company's financial 
performance. This is in line with the duties of employees charged by BUMN banks which are more oriented towards finding potential customers to buy products offered by banks such as savings, deposits, mortgages, insurance, and other products, which in turn will provide income to banks so that banks have good performance, and get profitability as expected. The VAHU variable has a negative influence on the ROE of SOE Banks because it is defined as one measure of intellectual capital that shows how much Value Added (VA) can be generated with funds spent on labor. Or according to Ulum (2009) that how much value added can be generated with funds released by labor. This shows that VAHU places more emphasis on expenditures given to its workforce such as salaries, bonuses, incentives and so on as working capital for employees in completing tasks given by employees, so the more human capital given by the company, the less profitability the company produces . STVA variable has an influence on the profitability (ROE) of BUMN banks, because STVA is defined to measure the amount of structural capital needed to produce one rupiah of value added and is an indication of the success of SC in value creation (Ulum, 2009). The value contained in structural capital depends on the value of human capital. The greater the value of human capital, the smaller the value of SC (structural capital) to be generated. This explains that any capital given by the company to employees, is expected to contribute to the profitability of the company, such as when employees receive salary or bonuses, it will increase their work motivation so that it will have an impact on profit contribution to the company.

\section{CONCLUSSION}

1. All independent variables namely VACA, VAHU, and STVA have a simultaneous influence on the ROE of BUMN banks as evidenced by the calculated $F$ value greater than the $F$ table value.

2. Partially (individually), the VACA and STVA variables have a positive influence on the ROE of BUMN banks, and the VAHU variable has a negative influence on the ROE of BUMN banks.

3. $29.3 \%$ of all independent variables (VAHU, VACA, and STVA) contribute to explain the profitability (ROE) of BUMN banks for the period 2013 to 2017, while $70.7 \%$ of the profitability (ROE) of BUMN banks may be influenced by other variables not examined.

\section{REFERENCESS}

Abdul Halim, dan Hasan Basridan Faisal. 2016. "Pengaruh Intellectual Capital terhadap Profitabilitas dan Dampaknya terhadap Harga Saham Perusahaan Sektor Keuangan Yang Terdaftar Di BEI". JBE. Vol.23, No.2, September 2016

Ahangar, R. G. (2011). The relationship between intellectual capital and 
financial performance: An empirical investigation in an Iranian company. African Journal of Business Management, Vol. 5(1), pp. 88-95.

Aminah \&Riduwan. 2015. Manfaat Laba dan Arus Kas dalam Menentukan Prediksi Kondisi Financial Distress. Jurnal Ilmu dan Riset Akuntansi Sekolah Tinggi Ilmu Ekonomi Indonesia Surabaya (Vol.4 No.5).

Bambang Riyanto, 1999. DasarDasarPembelanjaan.

BPFE.Yogyakarta.

Baridwan,zaki.2005. Intermediet Accounting. Yogyakarta:Graha Ilmu.

Bontis, N., Keow, W.C.C. \& Richardson, S. (2000), "Intellectual capital and business performance in Malaysian industries",Journal of Intellec-tual Capital,1(1),page 85-100.

Brooking, Annie 1996, IC: Core Assets for Third Millenium Enterprise. Thomson Business Press. London-England. Diadopsi oleh Partanen, Timo 1998:66 (39).

Faizin. 2016. Pengaruh Rasio Profitabilitas

Dan Rasio Pasar Terhadap Return Saham Studi Kasus Pada Perusahaan Manufaktur Sektor Food And Baverage Periode 2003-2012. Naskah publikasi. Surakarta : Program Studi Manajemen Fakultas Ekonomi Dan Bisnis Universitas Muhammadiyah Surakarta.

Fariana. 2014. Pengaruh Return On Equity(ROE), Net Profit Margin(NPM), Earning Per Share(EPS) dan Price Earning Ratio(PER) Terhadap ReturnSaham
Pada Perusahaan Propertydan Real EstateYang Terdaftar di Bursa Efek Indonesia Periode Tahun 2010-2013. Skripsi. Jakarta : Program Studi S-1 Akuntansi Fakultas Ekonomi Universitas Esa Unggul.

Febrianty, Jovan Febriantoko. 2018. "Pengaruh Intellectual Capital terhadap Profitabilitas perusahaan sektor makanan dan minuman di Indonesia”. Jurnal Akuntansi dan Pendidikan, Vol.7, No.1, April 2018.

Firer, S., \& Williams, M. (2003, September). Intellectual capital and traditional measures of corporate performance. Journal of Intellectual Capital, 4(3), 348-360. Brockman, J. (2014, April 15). Indonesian services sector finds its voice. International Trade Forum , 2014(1), 2. Rachmawati, D. (2012). Pengaruh Intellectual Capital terhadap Return On Asset (ROA) Perbankan. Jurnal Nominal, Volume 1, 34- 40.

Hanafi, Mamduh dan Abdul Halim. (2005). Analisis Laporan Keuangan. Edisi Kedua. UPP AMP YKPN, Yogyakarta.

Hendrayanti, Silvia. 2013. Analisis Pengaruh Faktor Internal Dan Eksternal Terhadap Profitabilitas Perbankan (Studi Pada Bank Umum Di IndonesiaPeriode Januari 2003Februari 2012). Diponegoro Journal of Manajemen, Vol.2 No.3. Tidak Diterbitkan: Semarang.

Kartika, M., \& Hatane, S. E. (2013). Pengaruh Intellectual Capital Terhadap Profitabilitas Perusahaan 
Perbankan yang Terdaftar di Bursa Efek Indonesia pada Tahun 20072011. Business Accounting Review, Vol.1, No.2, 14-25.

Kasmir. 2012.Analisis Laporan Keuangan, Jakarta: PT RajaGrafindo Persada

Kasmir. 2008a. Analisis Laporan Keuangan. Raja Grafindo Persada: Jakarta. 2010b. Analisa Laporan Keuangan. Edisi $\mathrm{Ke} 3$. Jakarta: Rajawali Pers.

Khaeru Nisa Aulia Urakhma. 2017. "Analisis Pengaruh Intellectual Capital Dan Inovasi Layanan Perbankan Terhadap Proftabilitas Bank Syariah Di Indonesia”. Skripsi, IAIN Salatiga. Juli 2017.

Laporan Keuangan Tahunan. Diunduh dalam website www.bni.co.id pada tanggal (kamis, 20/12-2018, 21;13)

Laporan Keuangan Tahunan. Diunduh dalam website www.btn.co.id padatanggal (kamis, 20/12-2018, $21 ; 13)$

Laporan Keuangan Tahunan. Diunduh dalam website www.idx.co.id pada tanggal (21 Februari 2019).

Marfuah, dan Maricha Ulfa, "Pengaruh Intellectual Capital Terhadap Profitabilitas, Produktivitas, dan Pertumbuhan Perusahaan Perbankan". EKBISI, Vol. IX, No.1, Desember 2014.

Martha Kartika, dan Saarce Elsye Hatane. 2013. "Pengaruh Intellectual Capital pada Profitabilitas Perusahaan Perbankan yang Terdaftar di BEI Pada Tahun 2007-2011”. BAR. Vol.1. No.2, 2013.
M. Hanafi, Mamduh. 2012. Analisis Laporan Keuangan. Yogyakarta: UPP STIM YKPN.

M Fardin Faza, Erna Hidayah, "Pengaruh Intellectual Capital Terhadap Profitabilitas, Produktivitas, Dan Nilai Perusahaan Pada Perusahaan Perbankan Yang Terdaftar Di Bursa Efek Indonesia (BEI)". EKBISI, Vol. VIII, No.2, Oktober 2014.

Muhammad. 2013. Metodologi Peneliti Ekonomi Islam Pendekatan Kuantitatif. Rajawali Press: Jakarta.

Mulyani, Ragil Teki. 2016. Analisis Pengaruh Variabel Makroekonomi terhadap Profitabilitas (ROA) Bank Umum Syariah di Indonesia. Skripsi. IAIN Salatiga Tidak Diterbitkan: Salatiga.

Profil perusahaan. Diambil dalam website www.britama.com pada tanggal (24 Maret 2019).

Pulic, A. (1998). Measuring the performance of intellectual potential in knowledge economy. Paper presented at the 2nd McMaster Word Congress on Measuring and Managing Intellectual Capital by the Austrian Team for Intellectual Potential.

Putri, Yuni Murdiana. 2016. Pengaruh Modal Intelektual Terhadap Profitabilitas dan Produktivitas Perusahaan Dalam Index LQ45. Jurnal Ilmu Dan Riset Akuntansi : Vol.5, No.3, Maret 2016.

Ramadhania Intan Cahyani, Tara Widiarti S, Jelita Listya Ferdiana . 2015. "Pengaruh Intellectual Capital 
terhadap Profitabilitas pada Perusahaan Manufaktur yang Terdaftar di Bursa Efek Indonesia". JRAP: Vol.2, No.1, Juni 2015.

Richard Suherman. 2017. "The Impact of Intellectual Capital toward Firm's Profitability and Market Value of Retail Companies Listed in Indonesia Stock Exchange (IDX) from 20132016”. Jurnal, iBuss Management.

Roos, J., G, Roos, N. C. Dragonetti, dan L. Edvinsson, 1997. Intellectual Capital: Navigating in the new business landscape. Houndsmills:Macmillan Business

Santoso, E.C., \& Setiawan, R. (n.d). Modal Intelektual dan Dampaknya bagi Keberhasilan Organisasi. Jurnal Manajemen, Fakultas Ekonomi, Universitas Kristen Maranatha Bandung, 4 (1). Sawarjuwono, T., Kadir, P.A. 2003. Intellectual Capital: Perlakuan, Pengukuran, dan Pelaporan (Sebuah Library Research). Jurnal Akuntansi dan Keuangan. Vol. 5 No.1. pp. 35-57.

Sawarjuwono, $\mathrm{T}$ dan Kadir, Agustine Prihatin. (2003). Intellectual Capital:
Perlakuan,Pengukuran, dan Pelaporan (sebuah library research): Jurnal Akuntansi danKeuangan. 5 (1), 35-37. Sekaran, Uma dan Bougie, Roger. (2010). Reseacrh Methods for Business. 5th Edition. A John Wiley and Sons, Ltd, Publication.

Stewart, T. (1997). Intellectual capital:

The New Wealth of Organization (Vol. 1st ed). New York: Doubleday / Currency.

Syamsudin, Lukman. (2007). Manajemen keuangan perusahaan. Jakarta:RajaGrafindo Persada.

Tuffahati Dhiagriya Kuspinta, Achmad Husaini. 2018. "Pengaruh Intellectual Capital terhadap Profitabilitas Perusahaan Manufaktur yang terdaftar di BEI periode 2014-2016". JAB. Vol.56, No.1. Maret 2018.

Ulum, Ihyaul. 2009. Intellectual Capital Konsep \& Kajian Empiris. Yogyakarta; Graha Ilmu

Ulum, I. (November 2008). Intellectual Capital Performance Sektor Perbankan di Indonesia. Jurnal Akuntansi dan Keuangan, Vol. 10, No. 2, 77-84. 